\title{
STRATIFIKASI SOSIAL DALAM NOVEL PABRIK KARYA PUTU WIJAYA
}

\author{
Awalludin $^{1}$ \& Samsul Anam ${ }^{2}$ \\ ${ }^{1,2}$ Program Studi Pendidikan Bahasa dan Sastra Indonesia, \\ Fakultas Keguruan dan IImu Pendidikan, Universitas Baturaja \\ Jln. Ratu Penghulu No. 02301 Karang Sari Baturaja OKU Sumatera Selatan, Indonesia \\ Email: ${ }^{1}$ awalludinawri@gmail.com, ${ }^{2}$ anam.samuel@yahoo.com
}

\begin{abstract}
Abstrak
Penelitian ini bertujuan untuk mendeskripsikan stratifikasi sosial yang terdapat dalam novel Pabrik karya Putu Wijaya dilihat dari unsur intrinsiknya. Metode yang digunakan dalam penelitian ini adalah metode deskriptif. Teknik pengumpulan data menggunakan teknik dokumentasi berupa novel Pabrik karya Putu Wijaya. Teknik analisis data dimulai dengan reduksi data, penyajian data, kesimpulan, dan verifikasi. Uji keabsahan data berupa uji validitas pakar terkait hasil analisis data penelitian. Hasil analisis stratifikasi sosial dalam novel ini menceritakan berbagai permasalahan tentang stratifikasi sosial dalam lingkungan sebuah pabrik. Stratifikasi sosial yang terjadi meliputi kelas-kelas dalam masyarakat, kriteria dalam lapisan masyarakat, dan kedudukan atau status dalam masyarakat yang dilihat berdasarkan kriteria-kriteria yang terdapat pada unsur-unsur intrinsik yang terdapat dalam novel tersebut. Stratifikasi sosial yang ada dalam novel Pabrik dapat dijadikan salah satu bahan ajar guru bahasa Indonesia dalam menjelaskan unsur pembangun novel.
\end{abstract}

Kata kunci: stratifikasi sosial, novel, unsur intrinsik, masyarakat

\section{SOCIAL STRATIFICATION IN PABRIK NOVEL BY PUTU WIJAYA}

\begin{abstract}
The purpose of this study was to describe social stratification in the novel of Pabrik written by Putu Wijaya based on the elements if its intrinsic. The method which was used in this research is descriptive method. Data analysis techniques begin with data reduction, data presentation, conclusions, and verification. Test the validity of the data in the form of expert validity test related to the results of analysis of research data. The results of the analysis of social stratification in this novel tell various problems about social stratification in the environment of a factory. Social stratification that occurs includes classes in society, criteria in the layers of society, and position or status in society that is seen based on the criteria contained in the intrinsic elements contained in the novel. Social stratification in the novel of Pabrik can be used as one of the teaching materials for Indonesian language teachers in explaining the building elements of the novel.
\end{abstract}

Keywords: social stratification, novel, intrinsic elements, society 


\section{A. Pendahuluan}

Kegiatan sastra tidak terlepas dari unsur masyarakat melalui intuisi sosial dengan menggunakan medium bahasa. Hal ini didukung oleh pendapat Wellek \& Warren (1995:109-110) yang menyatakan "Sastra adalah intuisi sosial yang memakai medium bahasa." Di samping itu, Abrams (dalam Wiyatmi, 2006:18) "Berdasarkan teori ekspresif satra dipandang sebagai ekspresi sastrawan, sebagai curahan perasaan atau luapan perasaan dan pikiran sastrawan, atau sebagai produk imajinasi sastrawan yang bekerja dengan persepsi-persepsi, pikiran-pikiaran atau perasaan-perasaannya." Dengan demikian, sastra itu mencerminkan pengalaman dan pandangan dalam kehidupan suatu masyarakat. Untuk itu, seorang pengarang harus peka terhadap situasi sosial yang terjadi dalam masyarakat sekitarnya melalui proses sosialisasi.

Proses sosialisasi dalam masyarakat tidak terlepas dari hubungan manusia yang satu dengan manusia yang lainnya, baik dalam pola interaksi dan komunikasi maupun ruang lingkup stratifikasi sosial yang berbeda. Stratifikasi sosial seperti inilah yang dapat menimbulkan fenomena-fenomena dalam kehidupan masyarakat, seperti yang terdapat dalam novel Pabrik karya Putu Wijaya ini.

Dalam novel ini tergambar bagaimana stratifikasi sosial dideskripsikan oleh pengarang melalui tokoh-tokoh cerita yang terlihat dari ungkapan-ungkapan yang terdapat dalam cerita tersebut. Melalui ungkapan-ungkapan yang dibicarakan oleh tokoh-tokoh cerita dapat diketahui adanya pelapisan kelas terhadap masalah sosial dalam lingkungannya. Oleh karena itu, penulis tertarik untuk melakukan analisis yang lebih mendalam tentang bagaimana stratifikasi sosial yang terdapat dalam novel Pabrik karya Putu Wijaya ini. Stratifikasi sosial yang terdapat dalam novel ini sarat dengan fenomena sosial para tokohnya. Fenomena sosial tersebut pasti kita jumpai dan mungkin akan kita alami dalam setiap kehidupan bermasyarakat yang majemuk. Sehubungan dengan itu, penulis menjadikan novel Pabrik ini sebagai sumber data penelitian ini.

Dalam sosiologi, sistem lapisan yang bertingkat disebut stratifikasi sosial (social stratification). Kata stratification berasal dari kata "Stratum" yang berarti 
lapisan. Tim Penyusun Kamus Pusat Bahasa (2008:860) menyatakan bahwa, "Stratifikasi adalah pembedaan penduduk atau masyarakat ke dalam kelas-kelas secara bertingkat atas dasar kekuasaan, hak-hak istimewa, dan prestise." Selanjutnya, Sorokin (dalam Soekanto, 1998:252) menyatakan "Social stratification adalah pembedaan penduduk atau masyarakat ke dalam kelas-kelas secara bertingkat (hierarkis)." Dalam versi bahasa Inggris, Sorokin (dalam Pateda (1987:78) menjelaskan, "Social stratification means the differentiation of a given population into hierarchically superposed classes." Berdasarkan pengertianpengertian tersebut dapat disimpulkan bahwa stratifikasi sosial adalah pelapisan penduduk atau masyarakat ke dalam kelas-kelas secara bertingkat. Sehubungan dengan latar belakang tersebut, rumusan masalah dalam penelitian ini adalah "Bagaimanakah stratifikasi sosial yang terdapat dalam novel Pabrik karya Putu Wijaya?"

Novel Pabrik karya Putu Wijaya ini sudah dilakukan penelitian pada aspek ideologi oleh Zamzuri (2017) dengan hasil penelitian berupa formasi ideologi yang terdapat dalam novel Pabrik hadir dalam tiga hubungan, yaitu hubungan kontradiktif antara ideologi otoritarianisme dengan demokrasi, hubungan korelatif antara ideologi liberalisme dengan hedonisme, serta hubungan bawahan antara ideologi otoritarianisme dengan liberalisme. Hasil penelitian ini menunjukkan bahwa kajian stratifikasi terhadap novel Pabrik karya Putu Wijaya belum diteliti.

Berdasarkan latar belakang dan rumusan masalah tersebut, penelitian ini bertujuan untuk mendeskripsikan stratifikasi sosial berupa kelas-kelas dalam masyarakat, kriteria dalam lapisan masyarakat, dan kedudukan atau status dalam masyarakat yang terdapat dalam novel Pabrik karya Putu Wijaya. Hasil penelitian ini diharapkan dapat bermanfaat baik secara teoretis maupun secara praktis. Secara teoretis, hasil penelitian ini diharapkan dapat memberikan pengembangan ilmu tentang stratifikasi sosial yang terdapat dalam novel Pabrik karya Putu Wijaya.

Secara praktis, penelitian ini diharapkan dapat bermanfaat bagi 1) pembaca, sebagai cerminan dalam melihat permasalahan yang terjadi pada manusia dan dapat memberikan kontribusi pengetahuan, menambah wawasan, 
dan pemahaman tentang stratifikasi sosial, 2) pengajaran sastra, hasil penelitian diharapkan dapat memperkenalkan struktur-struktur yang membangun sebuah novel sehingga muncul apresiasi terhadap novel tersebut serta dapat dijadikan sebagai bahan pengajaran bagi guru. Hal ini sesuai dengan pendapat Noermanzah (2017:28), bahwa karya sastra yang tercipta sebagai suatu kegiatan kreatif dan inovatif dalam betuk tulisan atau tercetak mempunyai nilai keindahan dan tidak dapat dipisahkan dengan pengajaran bahasa Indonesia. Kemudian, 3) bagi peneliti lain, sebagai informasi dan dasar bagi penelitian sejenis pada masa yang akan datang.

\section{B. Metode Penelitian}

Metode penelitian yang dilakukan adalah metode deskriptif kualitatif. Dalam penelitian ini, metode deskriptif kualitatif digunakan untuk mendeskripsikan unsurunsur stratifikasi dalam novel Pabrik karya Putu Wijaya. Sumber data penelitian ini adalah novel yang berjudul Pabrik karya Putu Wijaya. Teknik pengumpulan data menggunakan teknik dokumentasi berupa teks novel Pabrik karya Putu Wijaya.

Selanjutnya, Langkah-langkah prosedur analisis dalam penelitian ini adalah membaca novel, membuat sinopsis cerita, mengidentifikasi dan mengklasifikasi unsur-unsur intrinsik, menganalisis stratifikasi sosial, menginterpretasikan hubungan antara unsur intrinsik dan stratifikasi sosial, serta menyimpulkan hasil analisis data yang terdapat dalam novel tersebut (modifikasi dari Miles \& Huberman (2005). Uji keabsahan data penelitian menggunakan uji validitas pakar terkait hasil analisis data penelitian.

\section{Hasil Penelitian dan Pembahasan}

\section{Hasil Penelitian}

Novel yang berjudul Pabrik karya Putu Wijaya ini menceritakan stratifikasi sosial yang terjadi dalam sebuah pabrik di sebuah perkampungan penduduk. Tokoh yang terdapat dalam novel ini berjumlah 17 orang, yaitu Tirtoatmojo, Joni, Dargo, Dringgo, Mat Jegug, Susi, Maret, lyem, Budi, Tatang, Robert, Mei Lan, Muginah, Illyas, Eko, Siti, dan Zubeidi. Melalaui ungkapan-ungkapan yang 
diperankan oleh tokoh-tokoh tersebut dapat diketahui adanya permasalahan tentang stratifikasi social yang berkaitan dengan kelas-kelas dalam masyarakat, kriteria dalam lapisan masyarakat, dan kedudukan dalam masyarakat.

Kelas-kelas masyarakat yang terdapat dalam novel ini dibagi menjadi tiga tingkatan, yaitu kelas atas (upper class), kelas menengah (middle class), dan kelas bawah/rendah (lower class). Istilah kelas tidak selalu mempunyai arti yang sama, walaupun pada hakikatnya hal itu dapat mewujudkan sistem kedudukankedudukan yang sangat pokok dalam masyarakat yang bersangkutan.

Kelas atas ditandai dengan besarnya kekayaan, besarnya pengaruh baik dalam sektor masyarakat, perseorangan maupun buruh kecil, penghasilan tinggi, tingkat pendidikan yang tinggi, dan kestabilan kehidupan dalam keluarga. Dalam novel Pabrik ini, tokoh-tokoh yang termasuk dalam tingkatan atas adalah pimpinan perusahaan, yaitu Tirtoatmojo dan Joni. Untuk lebih jelasnya, kita dapat lihat pada kutipan berikut.

"Dengar baik-baik, kata Tirtoatmojo, Joni sudah kembali ini waktu. Tapi ikke suka dia injak ini rumah. Dus barang siapa ketemu dia lansa tidak boleh terima baik dia. Paham? Kamu orang semua mesti unjuk sikap tidak peduli. Ini rumah, pabrik, dan seluruh kekayaan ikke masih pegang penuh. Dia tidak bisa ambil over begitu saja tanpa ada persetujuan. Itu anak sudah terlalu jahat. Dia bisa sikat ini usaha yang susah payah dibangun, dalam satu dua hari untuk bermain judi. Paham?" (Wijaya, 2005:12).

Dari kutipan tersebut dapat disimpulkan bahwa Tirtoatmojo merupakan tokoh cerita yang termasuk dalam tingkatan atas. Hal ini disebabkan ia memiliki pekerjaan dan jabatan yang tinggi sebagai pemilik perusahaan. Dengan demikian, ia dapat memperoleh kemudahan dalam memenuhi kebutuhan hidupnya.

Dari segi perekonomian, Tirto juga memiliki kekayaan dan kemewahan yang membuatnya termasuk pada kelas atas. Hal ini dapat dilihat pada kutipan berikut.

"Setelah hujan reda, ia sempat menyelinap masuk ke dalam pabrik yang tak berapa jauh dari sana. Tirtoatmojo sedang mengalami kemujuran, sehingga pabriknya pesat sekali berkembang. Tak ternilai kekayaan yang ada dalam perusahaan itu. Perusahaan itu dalam waktu singkat telah menjadikannya orang kaya" (Wijaya, 2005:68).

Kutipan tersebut menandakan bahwa Tirto memang memiliki unsur kekayaan dan kemewahan yang tidak ternilai harganya, sehingga hal tersebut menjadikan status sosialnya berada pada tingkatan atas dalam masyarakat. 
Kelas menengah ditandai oleh pendapatan dan pendidikan yang cukup tinggi, rendahnya pengangguran, dan penghargaan yang tinggi terhadap kebutuhan menabung serta perencanaan masa depan. Kelas menengah ini dimiliki oleh staf-staf kantor atau perusahaan kecil, agen-agen pemasaran, dan manajemen tingkat menengah. Dalam novel Pabrik ini, kelas mengah dapat dilihat dari tokoh Mei Lan, sebagai seorang kasir perusahaan dan Budi yang sudah mampu membantu para buruh pabrik yang mendapat kesulitan dalam perekonomian mereka yang tidak mencukupi. Hal ini dapat kita lihat pada kutipan berikut.

"Tirtoatmojo yang sedang memberikan instruksi pada kasir Mei Lan, masih terbawa marahnya pada Dringgo. Ia merasa diludahi. Dia telah merasa cukup menahan diri terhadap Dringgo mengingat keluarganya yang menderita. Lewat illyas ia sering kali memberikan sumbangan agar keluarga yang termasuk paling melarat itu dapat diselamatkan. Karena kalau ada buruh yang terlalu miskin, akan berbahaya untuk semangat kerja buruh-buruh lainnya. la pun memikirkan bahwa sumbangan itu tak pernah sampai" (Wijaya, 2005:68).

Berdasarkan kutipan tersebut, tokoh Mei Lan dapat dikatakan termasuk dalam golongan kelas menengah karena ia memiliki jabatan sebagai seorang kasir perusahaan. Pada umumnya, seorang kasir perusahaan memiliki kecukupan dalam hal keuangan dan kebuthan hidupnya.

Selain Mei Lan, tokoh yang juga termasuk dalam kelas menengah adalah Budi. Hal ini dapat dilihat pada kutipan berikut.

“Kau anak baik, Dargo. Carilah kerja lain. Kau cerdas. Lagi pula kau mau kawin, bukan? Hah, aku tahu semua. Susi sudah cerita. Aku sudah berkawan dengan dia. Berapa kali aku menginap di sana. Susi tidak cerita? Ya, kasihan juga bekas peliharaan Tirtoatmojo itu. Maret bagaimana? Hah, tak usah dirahasiakan. Aku tahu semuanya. Aku sokong kau. Kalau mendapat kesulitan bilanglah. Aku bisa menolong" (Wijaya, 2005:92)

Kutipan tersebut menjelaskan bahwa Budi juga termasuk dalam kelas menengah karena ia telah sanggup untuk memberikan bantuan dalam hal perekonomian kepada orang lain yang sangat membutuhkannya.

Berikut ini adalah kutipan yang mendukung kutipan tersebut karena menjelaskan bahwa Budi telah memberi bantuan yang berupa uang kepada temannya, Dargo seperti yang tergambar pada kutipan berikut. 
"Lihat, ia merogoh uang dikutangnya. Lho, mana, mana. Tadi kusimpan di sini. Yakin aku membawanya. Barang kali terjatuh tadi. Aku bawa uang banyak. Uang dari Budi. Coba lihat, ada yang jatuh tadi. Di mana dia jatuh? Tolong Dargo, aku kehilangan!" (Wijaya, 2005:92).

Kutipan tersebut juga menjelaskan bahwa Budi telah memberikan bantuan uang cukup banyak kepada Dargo, sehingga dapat disimpulkan bahwa Budi memang termasuk pada kelas masyarakat yang menengah.

Kelas berikutnya adalah kelas bawah. Kelas ini terdiri dari kaum buruh kasar dan pekerja semi terampail yang terdapat di industri-industri, pengangguran yang menerima dana kesejahteraan, orang-orang yang buta huruf, serta orangorang yang memiliki penghasilan yang sangat kecil dan dianggap sebagai orang miskin. Masyarakat kelas bawah pada novel ini terdapat pada buruh-buruh pabrik, seperti Mat Jegug, lyem, dan Tatang. Untuk lebih jelasnya, keadaan tersebut dapat dilihat pada kutipan berikut.

"Tetapi kemudian muncul di pintu, muka bulat telur yang baru diangkat dari bantal. Babu Si lyem dengan rambut kusut, menggosok-gosokkan matanya mencari dalih untuk paman, supaya kekasihnya nanti tidak kena damprat karena alpa. Tirtoatmojo memakimaki dengan kotor seperti biasanya, kemudian Si lyem diam-diam menarik dirinya kembali ke atas dipan" (Wijaya, 2005:10).

Pada kutipan tersebut terlihat bahwa Si lyem adalah seorang babu di pabrik Tirtoatmojo yang sangat sulit perekonomiannya, sehingga ia bersedia bekerja sebagai seorang babu di perusahaan tersebut walaupun ia sering kena marah oleh majikannya. Namun, ia tetap bekerja karena hanya itulah yang dapat dijadikan sumber untuk melangsungkan kehidupannya.

Selain Si lyem, Tatang juga termasuk pada tingkatan masyarakat bawah. Hal ini dapat dilihat pada kutipan berikut.

\footnotetext{
"Tatang sendiri berdiri di luar karena ia tak mempunyai janji apa-apa. la hanya buruh biasa, yang kebetulan saja tergaet. Pada mulanya, ia hanyalah gelandangan biasa. Joni menemukannya sebagai pedagang obat di kompleks pelacuran, lalu menghubungkannya dengan pabrik. Pokoknya yang paling penting, ia adalah sahabat Joni, lebih dari buruhburuh lainnya" (Wijaya, 2005:34).
}

Kutipan tersebut menjelaskan bahwa Tatang adalah seorang buruh biasa yang diangkat oleh Joni untuk bekerja di pabriknya. Sebelumnya, ia adalah seorang gelandangan yang ada di kompleks pelacuran. Oleh sebab itu, ia tidak berani macam-macam dengan pabrik tersebut. 
Stratifikasi sosial yang terdapat dalam novel ini berkaitan juga dengan kriteria dalam masyarakat yang berbeda-beda. Untuk itu, Soekanto (1998:263) menggolongkan ukuran atau kriteria anggota masyarakat ke dalam suatu lapisan masyarakat. Kriteria lapisan masyarakat dapat diukur berdasarkan ukuran kekayaan yang dimiliki oleh seseorang. Dalam novel Pabrik ini, tokoh yang termasuk kriteria ini adalah Tirtoatmojo, pemilik perusahaan. Hal ini dapat dilihat dari kutipan berikut.

"Setelah hujan reda, ia sempat menyelinap masuk ke dalam pabrik yang tak berapa jauh dari sana. Tirtoatmojo sedang mengalami kemujuran, hingga pabriknya pesat sekali berkembang. Tak ternilai kekayaan yang ada dalam usaha itu. Perusahaan itu dalam waktu singkat telah menbjadikannya orang yang paling kaya" (Wijaya, 2005:24).

Kriteria lapisan masyarakat juga dapat ditentukan berdasarkan ukuran kekuasaan seperti jabatan atau wewenang seseorang dalam suatu masyarakat. Hal ini dapat dilihat pada kutipan berikut.

"Semua orang bikin fitnah dan kurang ajar sama kita orang. Ikke bikin ini pabrik, ikke tolong mereka dapat duit, kenapa terus-menerus ikke mesti terima perintah-perintah, Ikke tidak bisa istirahat, mereka mau tuntut semua dan ikke bisa ditendang, atau sastu kaligus ikke.Kacung-kacung itu mesti ikke bikin bersih. Ikke bisa cari lain orang yang lebih disiplin..." (Wijaya, 2005:45).

Kedua kutipan tersebut menjelaskan bahwa Tirtoatmojo adalah orang yang memikili kekayaan dan kekuasaan yang tinggi dalam masyarakat, sehingga dia dapat berbuat apa yang dia mau dan juga bertindak terhadap para buruh pabrik yang dipimpinnya tersebut. Selain itu, kriteria lapisan masyarakat ini juga ditentukan oleh ukuran kehormatan, golongan tua atau yang pernah berjasa, dan ukuran pengetahuan.

Stratifikasi sosial dalam novel Pabrik ini juga menceritakan permasalahan tentang kedudukan atau status dalam masyarakat. Soekanto (1998:265-268) menggambarkan ada dua staus soasial yang terdapat dalam masyarakat, yaitu ascribed status dan achieved status.

Ascribed status adalah kedudukan sesorang dalam masyarakat tanpa memperhatikan perbedaan-perbedaan rohaniah dan kemampuan. Kedudukan tersebut diperoleh karena kelahiran misalnya, kedudukan anak seorang bangsawan adalah bangsawan pula. Kedudukan seperti terdapat pada Joni yang 
menggantikan ayahnya sebagai direktur. Hal ini dapat kita lihat pada kutipan berikut.

\footnotetext{
“...ku kira waktunya tidak lama lagi.Karena itu aku harus pasti. Kalau Joni tidak jadi orang, biar pabrik ini saja menjadi anak angkatku. Segalanya boleh saja coba mengganyang, tetapi toh tetap bisa dimulai lagi, bahkan sedikit menyisahkan buah tanganku. Walaupun sudah pasti, di sana neraka" (Wijaya, 2005:49).
}

Achieved status adalah kedudukan yang dicapai oleh seseorang dengan usaha yang disengaja. Kedudukan ini tidak diperoleh atas dasar kelahiran. Akan tetapi, status ini bersifat terbuka bagi siapa saja yang memiliki kemampuan untuk meraihnya. Hal ini dapat kita lihat pada kutipan berikut.

\footnotetext{
"Samar-samar Tirto membayangkan masa kecilnya, masa mudanya, masa petualangannya, pertemuannya dengan Marie, usaha-usahanya, dan kemudian kesempatan baik serta buah-buah usahanya. Sebuah kisah sederhana yang bisa dimiliki setiap orang. Dan kini persoalan yang sedang dihadapinya. Hubungan yang tidak baik dengan Joni, buruh-buruhnya, dan sebagian orang. Kemudian harapan-harapan yang menggembirakan karena kemajuan pabrik jelas sekali. Penghargaan-penghargaan yang pernah diterimanya dari badan-badan sosial..." (Wijaya, 2005:49).
}

Kutipan tersebut menjelaskan bahwa Tirtoatmojo mendapatkan semua yang dimilikinya, baik rumah, pabrik, dan seluruh kekayaannya melalui usahausaha yang disengaja dan kerja keras dirinya dari muda sampai ia mendapatkan buah dari usahanya tersebut.

\section{Pembahasan}

Dalam novel Pabrik karya Putu Wijaya ini stratifikasi sosial diceritakan tentang konflik-konflik yang terjadi antara para buruh dan pemilik pabrik, yaitu Tirtoatmojo dan anaknya, Joni. Stratifikasi sosial yang diceritakan oleh Putu Wijaya dalam novel Pabrik dituangkan dalam tiga kelas, yaitu kelas atas, kelas sedang, dan kelas bawah sebagai penyebab konflik. Ketiga kelas yang digunakan dalam novel Pabrik menunjukkan bahwa Putu Wijaya sangat piawai menyajikan cerita sehingga novel yang dibaca menyajikan cerita yang bermanfaat juga memberikan kesan yang menarik bagi pembaca sehingga pembaca tidak bosan dalam membaca setiap peristiwa dalam novel. Hal ini sesuai dengan pendapat Sorokin (dalam Soekanto, 1998:252), bahwa stratifikasi sosial dalam novel harus menyajikan pembedaan penduduk atau masyarakat ke dalam kelas-kelas secara bertingkat (hierarkis). 
Cerita yang terjadi dalam novel ini diawali oleh status sosial kehidupan para tokoh yang terdapat dalam cerita tersebut. Tokoh Tirtoatmojo yang sangat berkuasa dan disegani oleh buruh-buruh pabriknya tersebut masih tidak membuat para buruhnya menjadi sejahtera. Sama halnya dengan Joni, dia memimpin pabrik menggantikan ayahnya, tetapi keadaan pabrik bukan menjadi lebih baik, sebaliknya semakin memburuk. Hal ini ini disebabkan oleh watak Joni yang lebih buruk daripada ayahnya, Tirtoatmojo.

Sementara itu, salah seorang buruh pabrik, Dringgo merasa tertekan dengan keadaan yang dialami buruh pabrik dan dirinya itu, sehingga ia mengajak rekan-rekan untuk melakukan aksi mogok kerja. Jika hal tersebut tidak berhasil, mereka mengancam akan membakar pabrik tersebut.

Pertentangan menjadi semakin rumit, sehingga terjadilah konflik antara buruh dan majikannya. Konflik ini mulai muncul karena pemilik pabrik tidak menepati janji-janji yang sering diucapkan untuk memberikan saham-saham, tunjangan, ganti rugi tanah yang diambil pabrik, serta janji akan mengangkat mereka menjadi karyawan di pabrik tersebut. Kenyataannya, hal itu hanyalah janjijanji belaka yang sama sekali tidak pernah ditepati oleh Tirtoatmojo dan Joni sebagai pemilik perusahaan tersebut. Konflik ini akhirnya berkembang menjadi permasalahan yang sangat besar, sehingga keadaan pabrik tidak lagi menyenangkan bagi para buruhnya.

Ketika pabrik dipimpin oleh Tirtoatmojo, konflik-konflik tersebut masih dapat diatasi dan tidak menjadi permasalahan yang besar, karena Tirto kadang-kadang masih suka memberi bantuan kepada para buruhnya melalui kasirnya, Mei Lan, sehingga para buruh tidak jadi melakukan demonstrasi terhadap perusahaan.

Ketika pabrik dipimpin oleh Joni, anak tirinya Tirtoatmojo ternyata keadaan perusahaan semakin memburuk dari sebelumnya karena watak Joni lebih buruk daripada Tirtoatmojo. Oleh sebab itu, hal ini menjadi penyebab utama puncak konflik yang terjadi dalam novel ini. Dringgo bersama buruh-buruh yang lain berhasil membakar pabrik tersebut sampai habis. Inilah hal yang sangat tragis yang menjadi akhir dari cerita yang terdapat dalam novel Pabrik karya Putu Wijaya ini. 
Permasalahan tersebut merupakan faktor utama yang menyebabkan adanya masalah tentang stratifikasi sosial dalam cerita tersebut. Wujud stratifikasi sosial ini tergambar melalui ungkapan-ungkapan yang diperankan oleh tokohtokoh cerita tentang kelas atau tingkatan masyarakat, kriteria dalam lapisan masyarakat, dan kedudukan masyarakat yang terdapat dalam novel tersebut. Kelas-kelas dalam masyarakat dibagi menjadi tiga, yaitu kelas atas, kelas menengah, dan kelas bawah. Stratifikasi sosial tersebut dilihat dari semua tokoh yang terlibat melalui percakapan-percakapan yang mereka ucapkan. Mereka merupakan masyarakat pabrik yang beraneka ragam kedudukannya di dalam pabrik tersebut mulai dari buruh, penjaga kantin, pembantu, kasir, karyawan sampai pimpinan perusahaan. Oleh sebab itu, stratifikasi sosial ini dapat disimpulkan ada di dalam cerita novel Pabrik karya Putu Wijaya ini.

Tokoh yang termasuk dalam kelas atas seperti Tirtoatmojo dan Joni sebagai pemilik perusahaan. Mereka merupakan tokoh-tokoh yang memiliki taraf perekonomian yang tinggi yang ditandai dengan kemampuan mereka dalam memenuhi kebutuhan hidup mereka termasuk kebutuhan terhadap barang mewah, pendidikan, memiliki pekerjaan tetap, penghasilan tinggi, jabatan tinggi, dan memiliki kekuasaan mengatur dan memimpin sekelompok individu yang terdapat dalam sebuah pabrik.

Tokoh-tokoh yang termasuk pada kelas menengah adalah Mei Lan dan Budi. Mereka memiliki taraf ekonomi yang bisa dikatakan sedang, yang ditandai oleh kemampuan mereka dalam memenuhi kebutuhan sehari-hari, mempunyai jabatan/pekerjaan, pendidikan yang cukup, dan sudah mampu memberikan bantuan kepada orang lain yang membutuhkan. Tokoh-tokoh yang termasuk dalam kelas atas dapat dilihat dari para buruh pabrik, seperti Mat Jegug, Si lyem, Tatang, dan buruh-buruh lainnya. Mereka merupakan tokoh-tokoh cerita yang memiliki taraf ekonomi yang rendah. Hal ini dapat dilihat dari tingkat pendidikan mereka yang rendah, gaji yang kecil, dan tidak memiliki kekuasaan.

Selain kelas sosial, stratifikasi sosial yang terjadi dalam novel ini juga membahas kriteria dalam lapisan masyarakat. Kriteria ini dapat kita lihat dari beberapa kriteria, seperti ukuran kekayaan, ukuran kekuasaan, ukuran kehormatan, golongan tua atau yang pernah berjasa, dan ukuran ilmu 
pengetahuan. Di samping itu, ada juga permasalahan tentang kedudukan dalam masyarakat yang dibagi menjadi dua, yaitu ascribed status dan achieved status. Tokoh-tokoh yang termasuk dalam kriteria ini adalah Joni dan Tirtoatmojo.

Berdasarkan realita yang ada dalam masyarakat, stratifikasi sosial yang terjadi dalam novel Pabrik karya Putu Wijaya ini hampir tidak pernah lagi kita jumpai dalam kehidupan sehari-hari, kecuali pada masyarakat tertentu seperti masyarakat agama Hindu yang masih menganut sistem kasta. Namun, hal ini pun sudah tidak begitu terlihat lagi dalam kehidupan masyarakat Hindu dewasa ini. Kenyataan ini mungkin disebabkan oleh drastisnya perkembangan zaman, seperti kemajuan ilmu pengetahuan dan teknologi. Oleh sebab itu, masyarakat sudah tidak lagi mempermasalahkan hal-hal yang berhubungan dengan tradisi lama seperti yang terdapat dalam novel Pabrik karya Putu Wijaya ini.

\section{Simpulan}

Berdasarkan hasil analisis dan pembahasan yang dilakukan dalam penelitian ini dapat disimpulkan bahwa stratifikasi sosial yang terdapat dalam novel Pabrik karya Putu Wijaya ini terbagi dalam kelas-kelas masyarakat yang meliputi tiga tingkatan, yaitu kelas atas, kelas menengah, dan kelas bawah/rendah yang menyebabkan terjadinya konflik. Tokoh yang termasuk dalam kelas atas adalah Tirtoatmojo dan Joni sebagai pemilik perusahaan. Tirtoatmojo dan Joni merupakan tokoh pemimpin yang suka mengobral janji kepada para bawahannya, tetapi semua itu tidak pernah ditepati. Lalu, tokoh yang termasuk pada kelas menengah adalah Mei Lan dan Budi. Mereka adalah tokoh yang sudah mampu memberikan bantuan kepada orang lain karena mereka sudah memiliki kedudukan dalam perusahaan yang dipimpin oleh Tirtoatmojo dan Joni. Selanjutnya, tokoh yang termasuk pada kelas bawah/rendah adalah para buruh kasar pabrik seperti Mat Jegug, Tatang, Si lyem, dan para buruh lainnya. Mereka termasuk kelas bawah karena mereka tidak memiliki kedudukan dalam perusahaan tersebut. Mereka hanyalah buruh biasa dan tidak tetap statusnya. Jadi, mereka hanya dapat mencukupi kebutuhan mereka sehari-hari yang masih serba kekurangan. 
Stratifikasi sosial dalam novel Pabrik ini juga ditentukan oleh kriteria dalam lapisan masyarakat yang dimiliki para tokoh yang berperan di dalam cerita. Kriteria ini ditentukan oleh ukuran kekayaan, ukuran kekuasaan, ukuran kehormatan, golongan tua atau yang pernah berjasa, dan ukuran ilmu pengetahuan. Kedudukan masyarakat dalam novel Pabrik ini terbagi dua, yaitu ascribed status dan achieved status. Hal ini juga merupakan penyebab munculnya masalah stratifikasi sosial dalam cerita tersebut. Tokoh-tokohnya adalah Joni dan Tirtoatmojo. Berdasarkan hal tersebut, dapat disimpulkan bahwa stratifikasi sosial memang terjadi dalam novel Pabrik karya Putu Wijaya ini, yaitu adanya kelaskelas masyarakat, kriteria dalam lapisan masyarakat, dan kedudukan (status) masyarakat dalam pabrik tersebut.

Setelah memperhatikan hasil analisis novel Pabrik karya Putu Wijaya tersebut dapat disarankan bahwa novel Pabrik karya Putu Wijaya ini perlu dibaca oleh semua orang karena ceritanya banyak mengandung pengetahuan dan wawasan tentang kehidupan sosial, khususnya mengenai stratifikasi sosial yang berkaitan dengan kelas-kelas yang terdapat dalam masyarakat. Berdasarkan hasil pengamatan, baik aspek isi maupun bahasa, novel Pabrik ini dapat diperkenalkan kepada siswa dan mahasiswa untuk meningkatkan kemampuan mengapresiasi karya sastra. Kemudian, bagi pembaca diharapkan dapat berpikir lebih dewasa dan bijaksana dalam menghadapi suatu persoalan yang terjadi, sehingga persoalan itu dapat diatasi dengan baik.

\section{Daftar Pustaka}

Miles, M. B. \& Huberman, A. M. (2005). Qualitative Data Analysis (terjemahan). Jakarta : UI Press.

Noermanzah, N. N. (2017). Plot in a Collection of Short Stories "Sakinah Bersamamu" Works of Asma Nadia with Feminimism Analysis. Humanus, 16(1), 27. doi:10.24036/jh.v16i1.7015

Pateda, M. (1987). Sosiolinguistik. Bandung: Angkasa.

Soekanto, S. (1998). Sosiologi: Suatu Pengantar. Jakarta: Raja Grafindo Persada. 
Tim Penyusun Kamus Pusat Bahasa. (2008). Kamus Besar Bahasa Indonesia. Jakarta: Balai Pustaka.

Wellek, R. dan Warren, A. (1995). Teori Kesusastraan. Jakarta: Gramedia Pustaka Utama.

Wijaya, P. (2005). Pabrik. Jakarta: Kompas Media Nusantara.

Wiyatmi. (2006). Pengantar Kajian Sastra. Yogyakarta: Penerbit Pustaka.

Zamzuri, A. (2017). Ideologi dalam Novel Pabrik Karya Putu Wijaya. Atavisme, 20(1), 14. doi:10.24257/atavisme.v20i1.303.

Silampari Bisa: Jurnal Penelitian Pendidikan Bahasa Indonesia, Daerah, dan Asing Vol. 2, No. 1, 2019 